\title{
Mexican Queso Chihuahua: Functional properties of aging cheese ${ }^{1}$
}

\author{
D. W. Olson, ${ }^{\star 2}$ D. L. Van Hekken, ${ }^{* 3}$ M. H. Tunick, ${ }^{\star}$ P. M. Tomasula, ${ }^{\star}$ F. J. Molina-Corral, $†$ and A. A. Gardea† \\ *USDA Agricultural Research Service, Eastern Regional Research Center, Dairy and Functional Foods Research Unit, Wyndmoor, PA 19038 \\ †Centro de Investigación en Alimentación y Desarrollo, Cuauhtémoc, Chihuahua 31570, México
}

\section{ABSTRACT}

Queso Chihuahua, a semi-hard cheese manufactured from raw milk (RM) in northern Mexico, is being replaced by pasteurized milk (PM) versions because of food safety concerns and the desire for longer shelf life. In this study, the functional traits of authentic Mexican Queso Chihuahua made from RM or PM were characterized to identify sources of variation and to determine if pasteurization of the cheese milk resulted in changes to the functional properties. Two brands of RM cheese and 2 brands of PM cheese obtained in 3 seasons of the year from 4 manufacturers in Chihuahua, Mexico, were analyzed after $0,4,8,12$, and 16 wk of storage at $4^{\circ} \mathrm{C}$. A color measurement spectrophotometer was used to collect color data before and after heating at $232^{\circ} \mathrm{C}$ for $5 \mathrm{~min}$ or $130^{\circ} \mathrm{C}$ for $75 \mathrm{~min}$. Meltability was measured using the Schreiber Melt Test on samples heated to $232^{\circ} \mathrm{C}$ for $5 \mathrm{~min}$. Sliceability (the force required to cut through a sample) was measured using a texture analyzer fitted with a wire cutter attachment. Proteolysis was tracked using sodium dodecyl sulfate-PAGE. Compared with PM cheeses, RM cheeses showed less browning upon heating, melted more at $232^{\circ} \mathrm{C}$, and initially required a greater cutting force. With aging, cheeses increased in meltability, decreased in whiteness when measured before heating, and required less cutting force to slice. Seasonal variations in the cheesemilk had minimal or no effect on the functional properties. The differences in the functional properties can be attributed, in part, to the mixed microflora present in the RM cheeses compared with the more homogeneous microflora added during the manufacture of PM cheeses. The degree of proteolysis and subsequent integrity of the cheese matrix contribute to melt, slice, and color properties of the RM and PM cheeses. Understanding the

\footnotetext{
Received September 30, 2010.

Accepted May 16, 2011.

${ }^{1}$ Mention of trade names or commercial products in this article is solely for the purpose of providing specific information and does not imply recommendation or endorsement by the U.S. Department of Agriculture.

${ }^{2}$ Current address: Louisiana State University, Agricultural Center, School of Animal Sciences, Baton Rouge, LA 70803.

${ }^{3}$ Corresponding author: diane.vanhekken@ars.usda.gov
}

functional properties of the authentic RM cheeses will help researchers and cheesemakers develop pasteurized versions that maintain the traditional traits desired in the cheeses.

Key words: Hispanic-style cheese, functional properties, Queso Chihuahua

\section{INTRODUCTION}

The Mexican Queso Chihuahua produced in the northern state of Chihuahua, Mexico, is a semi-hard cheese similar to Chester, a version of Cheddar that is higher in moisture and not aged as long. Although the cheese is traditionally made from raw milk (RM), pasteurization of the cheese milk is essential to minimize the risk of undesirable microflora in this style of cheese, which is typically sold and consumed within 3 to 6 wk after manufacture. To understand the quality traits found in this style of cheese, our laboratory has been characterizing the properties of Queso Chihuahua from Mexico and identifying sources of the variation among the commercial cheeses. The diverse microflora found in the RM Mexican Queso Chihuahua is altered significantly in the pasteurized milk (PM) versions (Bricker et al., 2005). The traditionally made RM cheese and the PM versions have similar chemical compositions but the traditional cheeses have a softer texture (Tunick et al., 2007; Van Hekken et al., 2007, 2008). The RM cheeses also have stronger acid and bitter flavor notes than the PM cheeses (Van Hekken et al., 2006, 2008). The notable variations observed among the different brands of Queso Chihuahua reflect the different manufacturing practices (including pasteurization of the milk; Tunick et al., 2008) and seasonality of the cheese milk (Tunick et al., 2007; Van Hekken et al., 2008). Other properties, such as the functional or cooking properties, that are important to the consumer have not yet been reported. Understanding the effect of pasteurization on the quality traits of Mexican Queso Chihuahua will help in the development of a pasteurized version with properties that consumers expect of this style of cheese.

Color, meltability, and sliceability are important functional properties for cheese because consumers will judge product quality based on these properties. Color is important for visual appeal and is quantified by $\mathrm{L}^{*}$ 
(white to black), $\mathrm{a}^{*}$ (red to green), and $\mathrm{b}^{*}$ (yellow to blue) values. The total color difference $(\Delta \mathbf{E}$, after heating compared with before heating) has application to the browning of cheese caused by the Maillard reaction. The reaction between reducing sugars and free amino groups occurs rapidly in milk above $110^{\circ} \mathrm{C}$ (Pagliarini et al., 1990). The resulting brown color may or may not be desirable, depending on the type of cheese and its utilization. Meltability refers to the extent that cheese flows and spreads during heating because the cheese structure loses its ability to support its own weight (Rowney et al., 1999). As with color upon heating, the extent of melt that is desirable depends on the type of cheese and the application. Many high-moisture Hispanic-style cheeses are fried, making no- or low-melt a desirable property (Torres and Chandan, 1981), but most semi-hard Hispanic-style cheeses, including Mexican Queso Chihuahua, are used in dishes where melting is desirable. Sliceability, another functional property valued by the consumer as it relates to the utilization of the cheese in food preparation, is the force required for a wire cutter to slice through a product. Determining the factors that affect the functional properties of the cheese will help the food industry produce a cheese that achieves the desired functionality in certain prepared Hispanic-style foods.

The objectives of this study were to evaluate the effects of pasteurization, seasonality of the cheese milk, and aging (up to 16 wk at $4^{\circ} \mathrm{C}$ ) on the functional properties of Mexican Queso Chihuahua made from raw and pasteurized milks.

\section{MATERIALS AND METHODS}

\section{Samples}

Two brands of commercial RM cheese and 2 brands of commercial PM cheese were obtained within $3 \mathrm{~d}$ of manufacture from 4 different cheese plants in Chihua- hua, Mexico. Based on our earlier characterization of the composition and rheology of commercial RM and PM Queso Chihuahua (Van Hekken et al., 2007), the 4 brands selected were representative of this style of cheese. The cheesemaking details that the manufacturers were willing to provide are given in Table 1 . Multiple vacuum-packed, 1-kg blocks of each brand of cheese were shipped to the Eastern Regional Research Center (Wyndmoor, PA) 3 times within a year (winter/ January, spring/May, and late summer/September) and stored at $4^{\circ} \mathrm{C}$. After $1,4,8,12$, and 16 wk of aging, 3 blocks of cheese from each brand were removed from storage and data were collected on composition, proteolysis, color, meltability, and sliceability.

\section{Composition}

The composition of each block of cheese was determined as reported by Tunick et al. (2007). Briefly, moisture content was measured in triplicate by loss on drying in a forced-air oven during heating at $130^{\circ} \mathrm{C}$ for 75 min (method 948.12; AOAC, 2000). Fat content was determined in duplicate by the modified Babcock method as described by Kosikowski and Mistry (1997). Nitrogen content was analyzed in duplicate using a Leco FP-2000 Protein/Nitrogen Analyzer (Leco Corp., St. Joseph, MI) with a combustion furnace operating temperature of $1,050^{\circ} \mathrm{C}$, and protein content was calculated by multiplying the nitrogen content by 6.38 . Salt $(\mathrm{NaCl})$ was calculated using high-range chloride titrators (Hach Co., Loveland, $\mathrm{CO}$ ). The $\mathrm{pH}$ was determined at 6 positions within a cheese block using a spear-tip probe (model 611, Orion Research Corp., Cambridge, MA).

\section{Protein Profiles}

Protein profiles were obtained for each brand after 1 , 8 , and 16 wk of storage at $4^{\circ} \mathrm{C}$ to track the extent of pro-

Table 1. Manufacture details for the 4 brands of Queso Chihuahua used in this study

\begin{tabular}{lcccc}
\hline & \multicolumn{4}{c}{ Brand } \\
\cline { 2 - 5 } Item & $\mathrm{A}$ & $\mathrm{B}$ & $\mathrm{C}$ & $\mathrm{D}$ \\
\hline Size of cheese plant $(\mathrm{kg}$ of cheese/d) & 2,300 & 3,600 & 1,600 & 760 \\
Milk refrigerated before cheesemaking $(\%)$ & 0 & 80 & 100 & 100 \\
CaCl ${ }_{2}$ added & No & Yes & No & Yes \\
Pasteurized & No & No & Yes & Yes \\
Commercial starter culture added & No & No & Yes & Yes \\
Commercial rennet added & Yes & Yes & Yes & Yes \\
Renneting time (min) & 30 & 40 & 30 & 40 \\
Cooking temperature $\left({ }^{\circ} \mathrm{C}\right)$ & 40 & 40 & 39 & 37 \\
Cooking time (min) & 20 & 60 & 15 & 45 \\
Milling size $(\mathrm{cm})$ & 4.0 & 1.25 & 2.0 & $\mathrm{NA}^{1}$ \\
Pressing time (h) & 24 & 20 & 6 & 15 \\
Pressing pressure $(\mathrm{kPa})$ & 207 & 124 & $\mathrm{NA}$ & 276 \\
\hline
\end{tabular}

${ }^{1} \mathrm{NA}=$ details not provided by manufacturer. 
teolysis within the cheeses. Water-soluble proteins were extracted from each cheese, SDS-PAGE conducted, and protein-peptide distribution determined as described by Van Hekken et al. (2004). Briefly, cheese samples were homogenized in Tris-EDTA buffer with added SDS and dithiothreitol and centrifuged to obtain a supernatant that was lyophilized. Extracts were solubilized in TrisEDTA-SDS buffer and mercaptoethanol was added before boiling the mixture. Samples were separated in an ultra-thin 20\% homogeneous polyacrylamide gel using the PhastSystem (Amersham Pharmacia Biotechnology, Piscataway, NJ). Gels were stained with Coomassie blue, destained in water-methanol-acetic acid solution, and scanned into a densitometer (Molecular Dynamics, Sunnyvale, CA). ImageQuant software (Molecular Dynamics) was used to quantify the bands.

\section{Melt and Color Values}

Cheese blocks were warmed to room temperature and 6 sample disks (5 $\mathrm{mm}$ thick and $38 \mathrm{~mm}$ in diameter) were cut from the interior of each block. A HunterLab Color Quest XE color measurement spectrophotometer (Hunter Associates Laboratory, Reston, VA) fitted with a 2.54-cm-diameter reflectance port was used to collect 4 measurements of the CIE $\mathrm{L}^{*}, \mathrm{a}^{*}$, and $\mathrm{b}^{*}$ values of each disk before heating; disks were rotated between measurements. The specular reflection was included to eliminate differences due to uneven surfaces and surface gloss. Each cheese disk was placed into a separate 100 $\times 15 \mathrm{~mm}$ Pyrex glass Petri dish; 3 disks were heated at $232^{\circ} \mathrm{C}$ for $5 \mathrm{~min}$ and the other 3 were heated at $130^{\circ} \mathrm{C}$ for $75 \mathrm{~min}$. After cooling, the Schreiber Melt Test, as described by Kosikowski and Mistry (1997), was used to measure the extent of melt of the disks that were heated at $232^{\circ} \mathrm{C}$ for $5 \mathrm{~min}$. This test measured the average extent of flow of the cheese disks on a series of concentric circles. A value of 1.0 indicates no change in disk diameter, and the value increases by 1.0 for every $1.0-\mathrm{cm}$ increase in diameter. Four color measurements were then again collected on all disks after heating and cooling. The averages of the $\mathrm{L}^{*}, \mathrm{a}^{*}$, and $\mathrm{b}^{*}$ values were used to calculate the magnitude of the total color difference $(\Delta \mathrm{E})$ using the following equation (Hunter, 1975):

$$
\Delta \mathrm{E}=\left(\Delta \mathrm{L}^{* 2}+\Delta \mathrm{a}^{*^{2}}+\Delta \mathrm{b}^{* 2}\right)^{1 / 2} .
$$

\section{Sliceability}

Sliceability, or firmness, of the cheese was measured using a TA-XT2 Texture Analyzer (Texture Technologies Corp., Scarsdale, NY) equipped with a 5-kg load cell as described by Olson et al. (2007). Briefly, cheese was warmed to ambient temperature $\left(22^{\circ} \mathrm{C}\right)$ and cut to obtain 2 or 4 pieces of cheese that were $45 \mathrm{~mm}$ long, 40 $\mathrm{mm}$ wide, and $25 \mathrm{~mm}$ thick. Each piece of cheese was placed on a TA-92 adjustable 3-point bend/snap fixture fitted into an HDP/90 heavy-duty platform. The 40$\mathrm{mm}$ side was sliced with an $\mathrm{A} / \mathrm{BC}$ butter cutter using pre-test and test speeds of $0.50 \mathrm{~mm} / \mathrm{s}$ and a post-speed of $10 \mathrm{~mm} / \mathrm{s}$; the automatic trigger was set to $50 \mathrm{~g}$. The mean force between 20 and $35 \mathrm{~s}$ after obtaining the trigger force was determined.

\section{Statistical Analysis}

The $\Delta \mathrm{E}$ for each heat treatment $\left(130^{\circ} \mathrm{C}\right.$ for $75 \mathrm{~min}$ and $232^{\circ} \mathrm{C}$ for $5 \mathrm{~min}$ ), meltability, sliceability, and proteolysis were analyzed as a split-plot design with 3 factors (raw/pasteurized, manufacturer nested within raw/pasteurized, and storage time) and with subsampling using the Mixed Models procedure of the SAS System for Windows, version 8 (SAS Institute, Inc., 1999). The Bonferroni $t$-test was used to determine significant differences among means, and differences were described as significant only if $P<0.05$.

\section{RESULTS AND DISCUSSION}

\section{Compositions and Proteolysis}

Composition of RM and PM Queso Chihuahua cheeses made during winter, spring, and summer are presented in Table 2. Overall, RM cheeses contained 38.7 $\pm 1.7 \%$ moisture, $32.4 \pm 2.5 \%$ fat, $25.0 \pm 0.4 \%$ protein, and $1.2 \pm 0.3 \%$ salt, and PM cheeses contained $40.8 \pm$ $1.6 \%$ moisture, $32.9 \pm 0.12 \%$ fat, $24.5 \pm 0.9 \%$ protein, and $1.5 \pm 0.1 \%$ salt. Compared with the RM cheeses, the PM cheeses tended to have higher moisture and salt contents; although moisture contents ranged from 37.4 to $41.6 \%$, statistically they were not significantly different $(P>0.05)$. The RM winter cheese had the lowest salt-in-moisture value. Protein levels were similar $(P>$ $0.05)$ in all brands throughout all seasons. Fat contents were more variable, with the highest levels obtained in the cheeses made in the summer and PM winter $(P$ $<0.05)$. The PM cheeses tended to have higher fat levels than RM cheeses in winter and spring. This trend was also noted in the fat in DM values, which ranged from 0.51 in winter RM cheese to 0.58 in summer PM cheese. A variety of reasons could explain the compositional differences, including farm-to-farm variation in milk quality, seasonal weather, and grazing or nutrition conditions, herd health, and sanitation issues. Compositional differences of the cheeses could also have varied due to variation in manufacturing conditions (Table 1). It is common to see differences among brand manufacturing practices. Although variation was seen among 
the 4 brands in this study in milk-handling practices, addition of $\mathrm{CaCl}_{2}$ to the cheesemilk, cooking time, milling size, and pressing parameters, it appeared that the composition of the cheeses was well clustered. In a larger survey of the manufacturers of Queso Chihuahua in this same region, Tunick et al. (2008) reported that variation in cheesemaking parameters such as size of knives used to cut the curd, cooking time and temperature, salting, and pressing time at a given pressure and temperature still resulted in cheese products of similar composition. The $\mathrm{pH}$ values for the cheeses were similar and ranged from 5.21 to 5.31.

The compositions of cheeses were within the ranges previously reported by our laboratory in a survey of 14 different brands of Queso Chihuahua from the same area (Van Hekken et al., 2007): 38 to $42 \%$ moisture, 27 to $34 \%$ fat, 22 to $27 \%$ protein, and 1.0 to $1.5 \%$ salt. The moisture and protein levels were similar to those previously reported for Queso Chihuahua although the fat content was higher (Diaz-Cinco et al., 1992; Saltijeral et al., 1999; Solano-Lopez and Hernandez-Sanchez, 2000). The samples met the Mexican Official Standards for this style of cheese: maximum of $45 \%$ moisture and minimums of $25 \%$ fat and $22 \%$ protein (Solano-Lopez and Hernandez-Sanchez, 2000).

Significant proteolysis occurred in all cheeses over the $16 \mathrm{wk}$ of storage (Table 3). The relative amount of $\alpha_{\mathrm{S}^{-}} \mathrm{CN}$ in both $\mathrm{RM}$ and PM cheeses significantly decreased from wk 1 to 16 . Degradation of $\beta-\mathrm{CN}$ was greater in the RM cheeses than in the PM cheeses. The largest decrease in $\alpha_{\mathrm{S1}^{-}} \mathrm{CN}$ and $\beta$-CN occurred in RM cheese made in the spring and in PM cheese made in the winter. As the major caseins were degraded, a concomitant increase was observed in large (25 to $16 \mathrm{kDa}$ ) and medium-sized (16 to $10 \mathrm{kDa}$ ) peptides. The relative amount of large and medium-sized peptides increased during storage and reflected the steady hydrolysis of the caseins. Pasteurization is known to alter the very complex system of plasminogen, activa- tors, and plasmin activity (Richardson, 1983; Sousa et al., 2001; Burbrink and Hayes, 2006), alter protein substrate availability within cheese (Lau et al., 1991), and reduce the microflora and associated enzymes (Bricker et al., 2005; Tunick et al., 2007). Bricker et al. (2005) reported that 8 brands of RM Queso Chihuahua typically contained more than $10^{7} \mathrm{cfu} / \mathrm{g}$ of leuconostoc, thermophilic and mesophilic cocci, thermophilic and mesophilic lactobacilli, and general mesophilic bacteria; PM cheeses contained counts 1 to 4 logs lower of the same categories of bacteria.

Composition of the cheese matrix plays an integral part in the functional properties of cheese as moisture hydrates the components and controls the soluble equilibrium within the matrix. The fat component interacts with the protein to impart flexibility to the cheese matrix, and in the case of heat stress, reduces the strength of the matrix to maintain its shape.

\section{Meltability}

Queso Chihuahua is known as a melting cheese and both RM and PM cheese had excellent melt properties throughout the year (no significant differences were found between the 3 seasons). The RM cheeses melted significantly more than the PM cheeses (Figure 1). The meltability of the RM cheeses increased steadily with aging, whereas the PM cheeses increased in the first month and then remained stable throughout the rest of the study. It was clear that the major change in the strength of the cheese matrix and its ability to maintain its shape when heat stressed occurred during the first month of storage. The continued increase in meltability of the RM cheese with age corresponded well with the higher degree of proteolysis reported in the RM cheeses with aging. When heat stress was applied to the cheese, the weakened matrix collapsed and flowed as the lipid portion changed from solid to liquid phase. Bogenrief and Olson (1995) found that the meltability

Table 2. Composition ${ }^{1}$ (mean $\pm \mathrm{SD}$ ) and $\mathrm{pH}$ values of fresh Mexican Queso Chihuahua made from raw milk (RM) or pasteurized milk (PM) during the winter, spring, and summer seasons

\begin{tabular}{|c|c|c|c|c|c|c|c|}
\hline $\begin{array}{l}\text { Season/milk } \\
\text { type }\end{array}$ & $\begin{array}{c}\text { Moisture } \\
(\%)\end{array}$ & $\begin{array}{c}\text { Protein } \\
(\%)\end{array}$ & $\begin{array}{l}\text { Fat } \\
(\%)\end{array}$ & $\begin{array}{l}\text { Salt } \\
(\%)\end{array}$ & FDM & $\mathrm{S} / \mathrm{M}$ & $\mathrm{pH}$ \\
\hline \multicolumn{8}{|l|}{ Winter } \\
\hline $\mathrm{RM}$ & $39.7 \pm 2.77$ & $24.7 \pm 0.41$ & $30.9 \pm 1.85$ & $1.05 \pm 0.27$ & $0.51 \pm 0.007$ & $0.027 \pm 0.009$ & $5.22 \pm 0.01$ \\
\hline \multicolumn{8}{|l|}{ Spring } \\
\hline $\mathrm{RM}$ & $38.8 \pm 0.32$ & $25.0 \pm 0.06$ & $30.9 \pm 0.21$ & $1.31 \pm 0.17$ & $0.51 \pm 0.001$ & $0.034 \pm 0.005$ & $5.27 \pm 0.01$ \\
\hline PM & $40.6 \pm 0.22$ & $25.4 \pm 0.13$ & $31.5 \pm 0.03$ & $1.41 \pm 0.03$ & $0.53 \pm 0.002$ & $0.035 \pm 0.001$ & $5.26 \pm 0.30$ \\
\hline PM & $41.5 \pm 0.03$ & $24.4 \pm 1.51$ & $33.7 \pm 0.36$ & $1.55 \pm 0.06$ & $0.58 \pm 0.006$ & $0.037 \pm 0.001$ & $5.24 \pm 0.01$ \\
\hline
\end{tabular}

${ }^{1} \mathrm{FDM}=$ fat in dry matter; $\mathrm{S} / \mathrm{M}=$ salt in moisture.

${ }^{2} \mathrm{NA}=$ data not available. 
Table 3. Protein distribution (\%) for the major proteins and peptides in Mexican Queso Chihuahua made from raw milk (RM) or pasteurized milk (PM) and aged for 1,8 , and 16 wk; obtained using SDS-PAGE

\begin{tabular}{|c|c|c|c|c|c|c|c|}
\hline \multirow{2}{*}{$\begin{array}{l}\text { Age of } \\
\text { cheese }\end{array}$} & \multirow[b]{2}{*}{ Protein/peptide } & \multicolumn{2}{|c|}{ Winter } & \multicolumn{2}{|c|}{ Spring } & \multicolumn{2}{|c|}{ Summer } \\
\hline & & $\mathrm{RM}$ & $\mathrm{PM}$ & $\mathrm{RM}$ & $\mathrm{PM}$ & $\mathrm{RM}$ & $\mathrm{PM}$ \\
\hline Wk 1 & $\begin{array}{l}\alpha_{\mathrm{S}^{-}} \mathrm{CN}^{1} \\
\alpha_{\mathrm{S} 1}-\mathrm{CN} \\
\beta-\mathrm{CN} \\
\mathrm{CN} \text { peptides, } 25-16 \mathrm{kDa} \\
\mathrm{CN} \text { peptides, } 16-10 \mathrm{kDa}\end{array}$ & $\begin{array}{c}3.6 \\
30.1^{\mathrm{a}} \\
30.1^{\mathrm{a}} \\
8.6^{\mathrm{d}} \\
21.3^{\mathrm{ab}}\end{array}$ & $\begin{array}{r}5.2 \\
28.5^{\mathrm{a}} \\
29.5^{\mathrm{a}} \\
14.2^{\mathrm{c}} \\
8.3^{\mathrm{b}}\end{array}$ & $\begin{array}{l}3.8 \\
34.0^{\mathrm{a}} \\
32.4^{\mathrm{a}} \\
10.8^{\mathrm{cd}} \\
14.2^{\mathrm{b}}\end{array}$ & $\begin{array}{l}8.3 \\
29.4^{\mathrm{a}} \\
27.4^{\mathrm{a}} \\
15.9^{\mathrm{c}} \\
11.3^{\mathrm{b}}\end{array}$ & $\begin{array}{r}7.5 \\
35.3^{\mathrm{a}} \\
33.2^{\mathrm{a}} \\
6.9^{\mathrm{d}} \\
14.3^{\mathrm{b}}\end{array}$ & $\begin{array}{r}10.0 \\
32.6^{\mathrm{a}} \\
31.3^{\mathrm{a}} \\
7.2^{\mathrm{d}} \\
16.2^{\mathrm{b}}\end{array}$ \\
\hline Wk 16 & $\begin{array}{l}\alpha_{\mathrm{S} 2}-\mathrm{CN} \\
\alpha_{\mathrm{S} 1}-\mathrm{CN} \\
\beta-\mathrm{CN} \\
\mathrm{CN} \text { peptides, } 25-16 \mathrm{kDa} \\
\mathrm{CN} \text { peptides, } 16-10 \mathrm{kDa}\end{array}$ & $\begin{array}{c}3.4 \\
12.4^{\mathrm{c}} \\
14.0^{\mathrm{c}} \\
28.2^{\mathrm{a}} \\
32.6^{\mathrm{a}}\end{array}$ & $\begin{array}{l}5.5^{\mathrm{bc}} \\
14.2^{\mathrm{bc}} \\
25.2^{\mathrm{ab}} \\
26.5^{\mathrm{a}} \\
23.3^{\mathrm{ab}}\end{array}$ & $\begin{array}{c}3.1 \\
11.4^{\mathrm{c}} \\
9.2^{\mathrm{c}} \\
24.2^{\mathrm{a}} \\
32.4^{\mathrm{a}}\end{array}$ & $\begin{array}{c}3.9 \\
9.6^{\mathrm{c}} \\
26.1^{\mathrm{ab}} \\
26.5^{\mathrm{a}} \\
22.1^{\mathrm{ab}}\end{array}$ & $\begin{array}{l}5.7^{\mathrm{c}} \\
12.7^{\mathrm{c}} \\
16.3^{\mathrm{c}} \\
15.6^{\mathrm{bc}} \\
37.9^{\mathrm{a}}\end{array}$ & $\begin{array}{l}7.6 \\
18.0^{\mathrm{b}} \\
28.7^{\mathrm{a}} \\
24.8^{\mathrm{a}} \\
19.5^{\mathrm{ab}}\end{array}$ \\
\hline
\end{tabular}

\footnotetext{
${ }^{\mathrm{a}-\mathrm{d}}$ Means in rows for the same protein or peptide (i.e., $\beta$-CN at wk 1,8 , and 16$)$ with different letters are significantly different $(P<0.05)$.
} Absence of letters indicates $P>0.05$.

of Cheddar increased with hydrolysis of $\alpha_{S^{-}}$casein. Tunick et al. (1993) reported that meltability of low-fat, high-moisture Mozzarella increased with proteolysis of $\alpha_{S 1}$-casein. The manufacturers of RM Queso Chihuahua in Mexico do not add commercial starter cultures to their cheesemilk and instead use the mixed microflora indigenous to that region and present in the raw milk (Bricker et al., 2005), which contribute to high enzymatic activities, proteolysis, and gas formation noted in the cheeses during aging. Although proteolysis has been cited by many as the main cause for increased meltability with age, several studies have suggested that the changing concentrations of soluble calcium and rate of acid production, especially during the first few weeks after manufacture, are the main forces behind the changes in cheese functionality (Choi et al., 2008; Lee et al., 2010).

\section{Overall Appearance and Color}

Queso Chihuahua was a firmly packed pressed cheese with few curd divisions visible, which is the expected appearance of this traditional ethnic cheese. The RM cheeses had multiple pinhole-sized gas holes that increased in size with aging and disrupted texture quality (Tunick et al., 2007). The PM cheeses also developed small gas holes with aging but not to the extent that texture was affected. Gases $\left(\mathrm{CO}_{2}\right.$ and $\left.\mathrm{H}_{2}\right)$ produced by the microflora present in the cheese would cause the formation of holes within the cheese matrix. Fresh RM Queso Chihuahua contains an abundant and diverse microflora compared with the PM cheeses (Bricker et al., 2005) and would account for the gas produced upon aging. Because of equipment issues, only color data from the spring and summer were evaluated.

Queso Chihuahua had a pale-yellow color with an average $\mathrm{L}^{*}$ value (black to white) of $84.2 \pm 2.02$, a* value (red to green) of $1.3 \pm 1.21$, and $\mathrm{b}^{*}$ value (yellow to blue) of $20.6 \pm 3.41$. The whiteness of the samples measured before heating decreased with aging. This loss of whiteness with aging is similar to that reported for unmelted low-fat Mozzarella (Metzger et al., 2001).

When exposed to $232^{\circ} \mathrm{C}$ for 5 min (broiling conditions), both RM and PM cheese disks became very thin and the PM cheese disks browned heavily on the outer

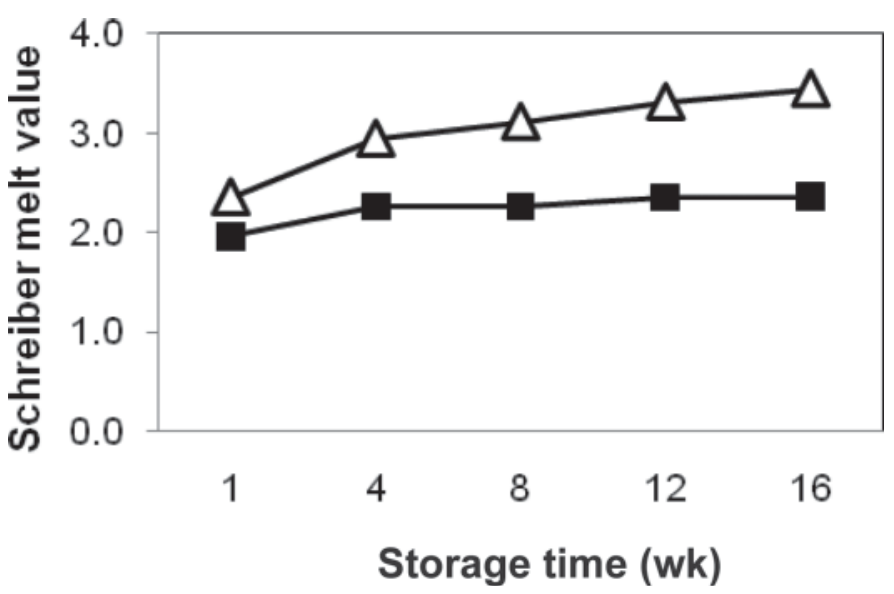

Figure 1. Schreiber melt values for Mexican Queso Chihuahua cheeses made from raw $(\Delta)$ and pasteurized $(\boldsymbol{\square})$ milks as a function of storage time. 
edges (Figure 2, panels a and b). We avoided the edges of the disks when color was measured; therefore, the $\Delta \mathrm{E}$ does not reflect this browning in the PM cheeses. Although no seasonal effects were found, the RM and $\mathrm{PM}$ cheeses had noticeable differences in their $\Delta \mathrm{E}$ values as they aged (Figure 3 ). The $\Delta \mathrm{E}$ value for the $\mathrm{RM}$ cheeses increased significantly from 8.2 to 14.6 over the 16 -wk study, whereas the $\Delta \mathrm{E}$ values for PM cheeses were stable throughout the study and ranged from 5.6 to 7.2 . By wk 8 , the RM cheeses had significantly higher $\Delta \mathrm{E}$ values than the $\mathrm{PM}$ cheeses.

When exposed to $130^{\circ} \mathrm{C}$ for 75 min (low-temperature baking conditions), disks of RM and PM cheeses puffed rather than thinned as they melted (Figure 2, panels c and d, respectively). The most noticeable difference was the extensive browning noted in the PM cheeses, the $\Delta \mathrm{E}$ values of which ranged from 38.3 to 52.5 , whereas the $\Delta \mathrm{E}$ values for the $\mathrm{RM}$ cheeses ranged from 14.1 to 16.8 (Figure 4). No significant seasonal or aging effects were found.

Upon heating, the RM cheeses retained a whitish color that would give a light acceptable appearance to any food dish to which it is added. The PM cheeses showed significant browning when heated that would be considered unacceptable in many Hispanic dishes. Because of the location of the browning on the $232^{\circ} \mathrm{C}$ cheese disks, a)

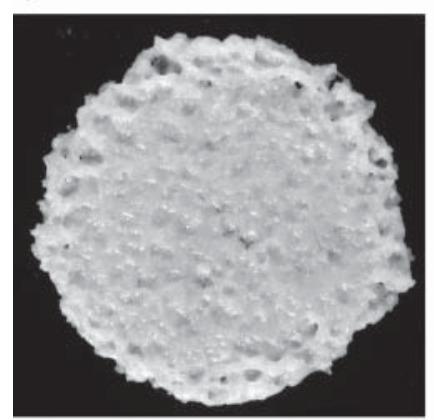

c)

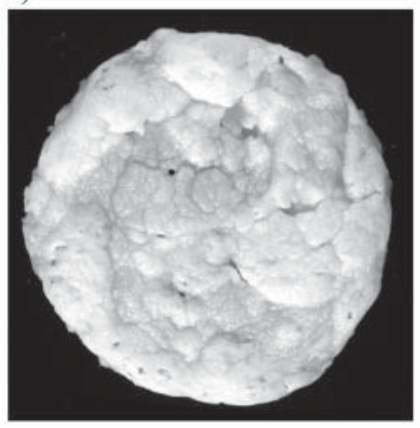

b)

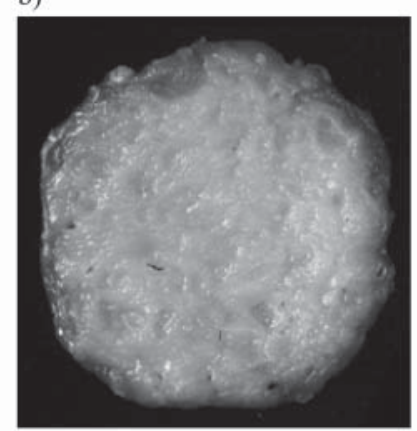

d)

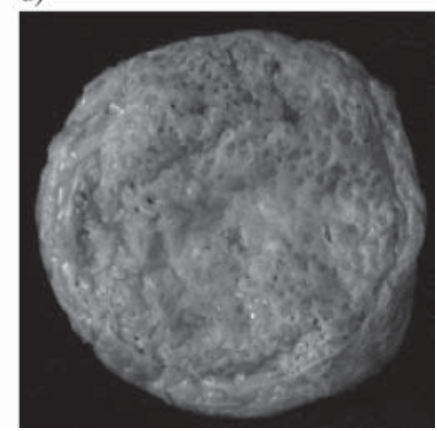

Figure 2. Disks of raw milk (panels a and c) and pasteurized milk (panels b and d) Mexican Queso Chihuahua cheeses after heating at $232^{\circ} \mathrm{C}$ (panels a and b) for 5 min or at $130^{\circ} \mathrm{C}$ for $75 \mathrm{~min}$ (panels c and d).

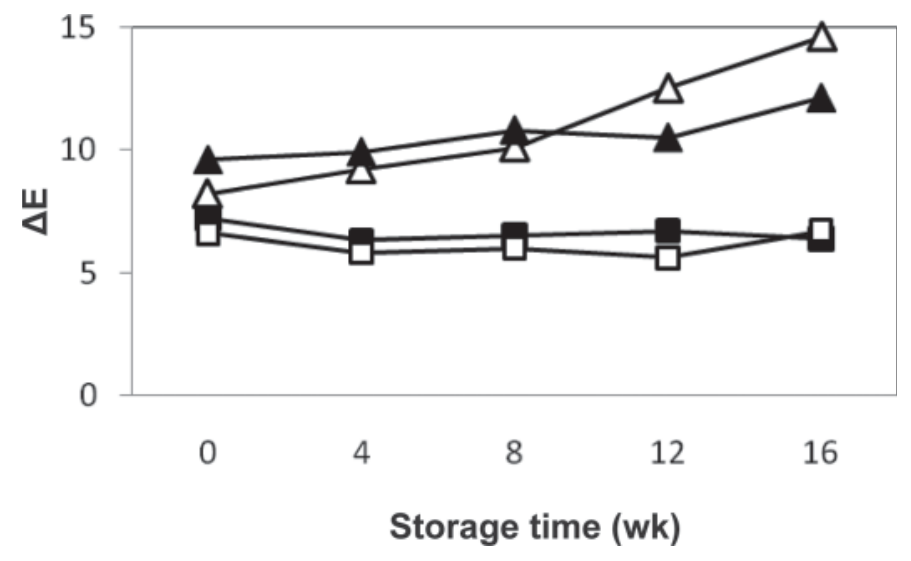

Figure 3. The total color change $(\Delta \mathrm{E})$ after a $232^{\circ} \mathrm{C}-5$-min heat treatment for Mexican Queso Chihuahua cheeses made from raw milk $(\mathrm{RM})$ or pasteurized milk (PM) in spring (Sp) or summer (Sum) as a function of storage time: $\Delta=\mathrm{RM} \mathrm{Sp} ; \boldsymbol{\Lambda}=\mathrm{RM}$ Sum; $\square=\mathrm{PM} \mathrm{Sp}$; $\mathbf{\square}=$ PM Sum

only the browning noted in the PM cheeses heated at $130^{\circ} \mathrm{C}$ for 75 min was quantified. This brown color can also be shown by hue angles and chroma values (data not shown). The PM cheeses heated at $130^{\circ} \mathrm{C}$ for 75 min typically had hue angles close to $45^{\circ}$, unlike the other samples in the study. The chroma values of these cheeses tended to be lower than those of the remaining samples. Riha and Wendorff (1993) reported that the color represented by a hue angle of $45^{\circ}$ would change from orange to brown as the chroma is decreased. Although a brown color can be explained by the relationship between $\mathrm{a}^{*}$ and $\mathrm{b}^{*}$ values, Bley et al. (1985) used total color difference, $\Delta \mathrm{E}$, to indicate the intensity of the brown color.

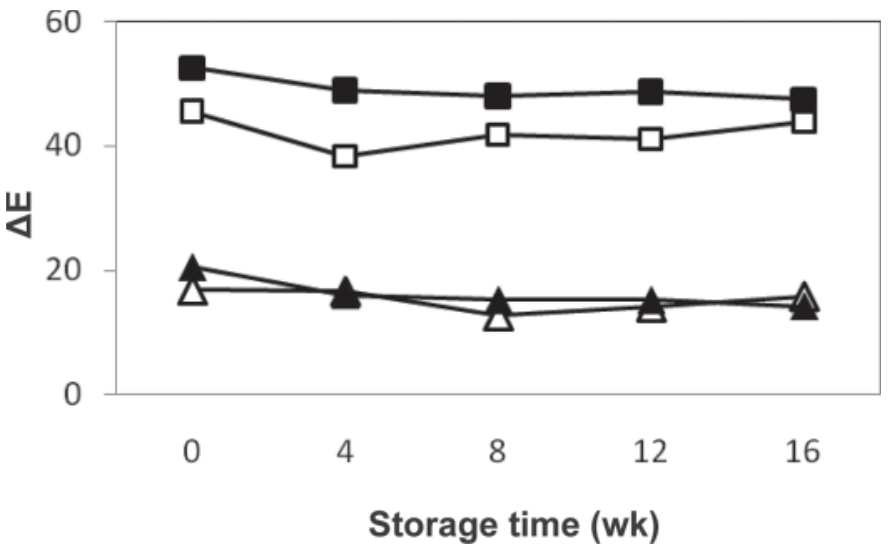

Figure 4. The total color change $(\Delta \mathrm{E})$ after a $130^{\circ} \mathrm{C}-75$-min heat treatment for Mexican Queso Chihuahua cheeses made from raw milk $(\mathrm{RM})$ or pasteurized milk (PM) in spring (Sp) or summer (Sum) as a function of storage time: $\Delta=\mathrm{RM} \mathrm{Sp} ; \boldsymbol{\Lambda}=\mathrm{RM}$ Sum; $\square=\mathrm{PM} \mathrm{Sp}$; $\mathbf{\square}=$ PM Sum. 


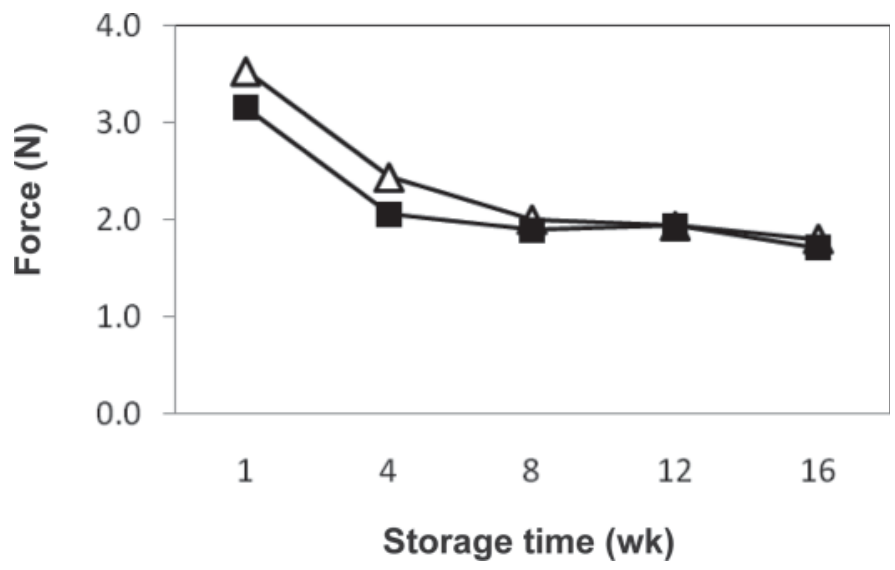

Figure 5. The force required to slice Mexican Queso Chihuahua cheeses made from raw $(\Delta)$ and pasteurized $(\mathbf{\square})$ milks as a function of storage time.

In Mozzarella studies, the browning that occurred upon heating was correlated with the galactose concentration (Bley et al., 1985; Johnson and Olson, 1985). More browning in the PM cheeses than in the RM cheeses after heat treatment would imply a higher galactose concentration in the PM cheeses. Several studies have shown that cheeses made with galactosefermenting strains of Streptococcus and Lactobacillus do not brown when heated (Bley et al., 1985; Johnson and Olson, 1985). The formation of galactose from lactose or the utilization of galactose by bacteria in RM cheeses compared with PM cheeses during storage would likely be different because RM cheese has a diverse microflora, whereas PM cheese has a more homogeneous microflora provided by the addition of dairy cultures (Bricker et al., 2005).

\section{Sliceability}

The force required to slice the cheese decreased in the first $4 \mathrm{wk}$ of aging and then remained stable for the remainder of the study (up to $16 \mathrm{wk}$ of storage; Figure $5)$. No significant seasonal effects were found. Initially, more force was required to slice the fresh RM cheeses than the PM cheeses, but after 8 wk of aging, they required the same amount of force. The early difference between the RM and PM cheeses may be related to the slightly lower moisture content in the RM cheeses compared with the PM cheeses. Improved sliceability (easier to pass a wire through the body of the cheese) with aging was related to the proteolysis that occurred during storage, which resulted in a softening of the protein matrix. Olson et al. (2007) reported high correlations between proteolysis and sliceability in semi-hard cheeses made from goat milk and found that slicing force decreased significantly during the first $8 \mathrm{wk}$ of storage. Sliceability is one way to measure the strength of the cheese matrix. Another way is to measure the hardness of the cheese by measuring the force required to compress a cheese sample using texture profile analysis. Tunick et al. (2007) reported a decrease in hardness with aging for both PM and RM cheeses and noted that the RM cheeses showed more seasonal variation than the PM cheeses.

\section{CONCLUSIONS}

Pasteurization of the cheesemilk and aging of the cheese influenced the functional properties (meltability, sliceability, and extent of color change after heating) of Queso Chihuahua, whereas seasonal milk effects had minimal or no effect. Pasteurization of the cheesemilk altered the microflora in the milk. The addition of starter cultures in making the PM cheeses ensured significant proteolysis occurred with aging. Compared with the PM cheeses, the RM cheeses had greater degradation of $\beta-\mathrm{CN}$, suggesting that different enzymes were present in the RM cheeses. Degradation of the proteins alters the integrity of the cheese matrix, which affects how well the cheese melts and slices and its appearance after cooking. Therefore, the changes in the functional properties caused by pasteurization of the cheesemilk and aging of the cheese will affect the optimal utilization of Queso Chihuahua. An adjunct culture may be required in pasteurized versions to obtain the properties found in the RM cheese. Taking these factors into account will enable the development of a pasteurized version of Queso Chihuahua that has the functional properties found in the traditionally made RM cheeses.

\section{ACKNOWLEDGMENTS}

The authors thank James Shieh (USDA-ARS, Wyndmoor, PA) for performing the compositional analysis and John Phillips (USDA-ARS, Wyndmoor, PA) for assistance with statistical analysis.

\section{REFERENCES}

AOAC. 2000. Pages 33-58 in Official Methods of Analysis. 17th ed. AOAC International, Gaithersburg, MD.

Bley, M. E., M. E. Johnson, and N. F. Olson. 1985. Factors affecting nonenzymatic browning of process cheese. J. Dairy Sci. 68:555561.

Bogenrief, D. D., and N. F. Olson. 1995. Hydrolysis of beta-casein increases Cheddar cheese meltability. Milchwissenschaft 50:678682.

Bricker, A. L., D. L. Van Hekken, V. M. Guerrero, and A. A. Gardea. 2005. Microflora isolated from Mexican Mennonite-style cheeses. Food Prot. Trends 25:637-640.

Burbrink, C. N., and K. D. Hayes. 2006. Effect of thermal treatment on the activation of bovine plasminogen. Int. Dairy J. 16:580-585.

Choi, J., D. S. Horne, M. E. Johnson, and J. A. Lucey. 2008. Effects of the concentration of insoluble calcium phosphate associated with 
casein micelles on the functionality of directly acidified cheese. J. Dairy Sci. 91:513-522.

Diaz-Cinco, M. E., O. Fraijo, P. Grajeda, J. Lozano-Taylor, and E. Gonzalez de Mejia. 1992. Microbial and chemical analysis of Chihuahua cheese and relationship to histamine and tyramine. J. Food Sci. 57:355-356., 365.

Hunter, R. S. 1975. The Measurement of Appearance. John Wiley and Sons Inc., New York, NY.

Johnson, M. E., and N. F. Olson. 1985. Nonenzymatic browning of Mozzarella cheese. J. Dairy Sci. 68:3143-3147.

Kosikowski, F. V., and V. V. Mistry. 1997. Cheese and fermented foods. Pages 212 and 259 in Procedures and Analysis. Vol. 2. 3rd ed. F. V. Kosikowski, ed. LLC, Westport, CT.

Lau, K. Y., D. M. Barbano, and R. R. Rasmussen. 1991. Influence of pasteurization of milk on protein breakdown in Cheddar cheese during aging. J. Dairy Sci. 74:727-740.

Lee, M. R., M. E. Johnson, S. Govinasamy-Lucey, J. J. Jaeggi, and J. A. Lucey. 2010. Insoluble calcium content and rheological properties of Colby cheese during ripening . J. Dairy Sci. 93:1844-1853.

Metzger, L. E. D. M. Barbano, P. S. Kindstedt, and M. R. Guo. 2001. Effect of milk preacidification on low fat Mozzarella cheese: II. Chemical and functional properties during storage. J. Dairy Sci. $84: 1348-1356$

Olson, D. W., D. L. Van Hekken, M. H. Tunick, K. A. Soryal, and S. S. Zeng. 2007. Effects of aging on functional properties of caprine milk made into Cheddar- and Colby-like cheeses. Small Rumin. Res. 70:218-227.

Pagliarini, E., M. Vernile, and C. Peri. 1990. Kinetic study on color changes in milk due to heat. J. Food Sci. 55:1766-1767.

Richardson, B. C. 1983. The proteinases of bovine milk and the effect of pasteurization on their activity. N.Z. J. Dairy Sci. Technol. 18:233-245.

Riha, W. E., and W. L. Wendorff. 1993. Evaluation of color in smoked cheese by sensory and objective methods. J. Dairy Sci. 76:14911497.

Rowney, M., P. Roupas, M. W. Hickey, and D. W. Everett. 1999 Factors affecting the functionality of Mozzarella cheese. Aust. J. Dairy Technol. 54:94-102.
Saltijeral, J. A., V. B. Alvarez, and B. Garcia. 1999. Presence of Listeria in Mexican cheeses. J. Food Saf. 19:241-247.

SAS Institute. 1999. SAS/STAT User's Guide, Version 8. SAS Institute Inc., Cary, NC.

Solano-Lopez, C., and H. Hernandez-Sanchez. 2000. Behaviour of Listeria monocytogenes during the manufacture and ripening of Manchego and Chihuahua Mexican cheeses. Int. J. Food Microbiol. 62:149-153.

Sousa, M. J., Y. Ardo, and P. L. H. Mc Sweeney. 2001. Advances in the study of proteolysis during cheese ripening. Int. Dairy J. $11: 327-345$.

Torres, N., and R. C. Chandan. 1981. Flavor and texture development in Latin American white cheese. J. Dairy Sci. 64:2161-2169.

Tunick, M. H., K. L. Mackey, J. J. Shieh, P. W. Smith, P. Cooke, and E. L. Malin. 1993. Rheology and microstructure of low-fat Mozzarella cheese. Int. Dairy J. 3:649-662.

Tunick, M. H., D. L. Van Hekken, J. E. Call, F. J. Molina-Corral, and A. A. Gardea. 2007. Queso Chihuahua: Effects of seasonality of cheesemilk on rheology. Int. J. Dairy Technol. 60:13-21.

Tunick, M. H., D. L. Van Hekken, F. J. Molina-Corral, P. M. Tomasula, J. E. Call, J. B. Luchansky, and A. A. Gardea. 2008. Queso Chihuahua: Manufacturing procedures, composition, protein profiles, and microbiology. Int. J. Dairy Technol. 61:62-69.

Van Hekken, D. L., M. A. Drake, J. Molina-Corral, V. M. Guerrero Prieto, and A. A. Gardea. 2006. Mexican Chihuahua cheese: Sensory profiles of young cheese. J. Dairy Sci. 89:3729-3738.

Van Hekken, D. L., M. A. Drake, M. H. Tunick, V. M. Guerrero, F. J. Molina-Corral, and A. A. Gardea. 2008. Effect of pasteurization and season on the sensorial and rheological traits of Mexican Queso Chihuahua. Dairy Sci. Technol. 88:525-536.

Van Hekken, D. L., M. H. Tunick, and Y. W. Park. 2004. Rheological and proteolytic properties of Monterey Jack goat's milk cheese during aging. J. Agric. Food Chem. 52:5372-5377.

Van Hekken, D. L., M. H. Tunick, P. M. Tomasula, F. J. Molina-Corral, and A. A. Gardea. 2007. Mexican Queso Chihuahua: Rheology of fresh cheese. Int. J. Dairy Technol. 60:5-12. 